\title{
Sengketa Laut Tiongkok Selatan: Ancaman Bagi Komunitas Keamanan ASEAN?
}

\author{
Agus Haryanto dan Arief Bakhtiar D. \\ Universitas Jenderal Soedirman dan Universitas Gadjah Mada
}

\begin{abstract}
ABSTRAK
Perbedaan sikap diantara negara ASEAN seringkali disebut sebagai titik kegagalan pembentukan Komunitas Keamanan. Tulisan ini menelaah lebih jauh mengenai komponen pembentuk Komunitas Keamanan dalam konteks sengketa LTS. Menggunakan argument Karl Deutch yang menyatakan ada tiga hal yang perlu diperhatikan dalam membentuk masyarakat keamanan, yaitu (1) para pembuat kebijakan dan masyarakat berhenti merenungkan kemungkinan perang (2) negara berhenti mengalokasikan sumber daya untuk membangun kemampuan militer yang ditujukan kepada negara lain dan (3) ada penerimaan dan kepatuhan yang ketat terhadap aturan-aturan dan perjanjian tertentu bila tujuan kolektif unit-unit tidak selaras. Tulisan ini berargumen bahwa ketiga komponen pembentuk Komunitas Keamanan terganggu ketika ASEAN menghadapi sengketa LTS. Pertama, mengganggu upaya penyebaran norma-norma ASEAN. Kedua, mengganggu upaya mekanisme pencegahan konflik. Ketiga, menghambat ikatan kepercayaan diantara anggota ASEAN.
\end{abstract}

Kata-Kata Kunci: Sengketa, Laut Tiongkok Selatan, ASEAN, Komunitas Keamanan.

A lack of unity among ASEAN members often referred as failure of security commmunity progress in ASEAN. This research analyzes three components of security community in the context of the South China Sea dispute. In accordance with Karl Deutch's security community theory, there are three things that considered to build security community: (1) talks about possibility of war; (2) the allocation of resources to build military power, and (3) acceptance and obedience to certain rules and agreements. This paper argues that South China Sea dispute interfered ASEAN to build security community. First, the issue disrupts efforts to spread ASEAN's norms. Secondly, the situation has interfered conflict prevention. Third, the differences attitude of ASEAN members caused difficulty to establish a conflict resolution mechanism within ASEAN.

Keywords: Conflict, South China Sea, ASEAN, Security Community. 
Klaim tumpang tindih kedaulatan di Laut Tiongkok Selatan (LTS) ${ }^{1}$ belum memperlihatkan situasi yang akan berakhir. Selama lebih dari satu dekade, pemberitaan di media-media memperlihatkan situasi memanas yang terjadi di Laut Tiongkok Selatan. Sedikitnya enam pihak terlibat langsung, yaitu Tiongkok, Taiwan, Vietnam, Filipina, Malaysia, dan Brunei Darussalam. ${ }^{2}$ Pemberitaan-pemberitaan di media selama ini cenderung menonjolkan sengketa perlombaan dan kekuatan militer antara Tiongkok, Filipina, dan Vietnam di kawasan tersebut, misalnya dengan menyelenggarakan latihan militer dan membangun basis-basis militer yang dilihat sebagai pamer kekuatan. Ketiga negara tersebut bahkan saling melakukan provokasi melalui media massa di negara masing-masing. Yang membuat sengketa Laut Tiongkok Selatan menarik adalah bahwa konflik ini bersamaan dengan dua perkembangan dunia terakhir. Pertama, kekuatan Tiongkok yang semakin disegani dunia, terutama dibidang kemajuan ekonomi. Kedua, peralihan kebijakan luar negeri Amerika Serikat menjadi "high-profile intervention" di kawasan Pasifik. Selain Tiongkok dan AS, India dan Australia juga sangat mungkin terlibat dalam pusara konflik. Melihat beberapa perkembangan dan fenomena itu, Laut Tiongkok Selatan diperkirakan akan menjadi salah satu pusat konflik pasca-Perang Dingin (Acharya 2009, Kaplan 2011, dan Minsky 2015).

Dengan rawannya situasi di LTS tersebut, penelitian ini menjawab pertanyaan mengenai mengapa sengketa LTS menjadi ancaman terhadap Komunitas Keamanan ASEAN 2015. Penulis berargumen, ada tiga hal yang menyebabkan sengketa LTS berpotensi menjadi ancaman yang serius bagi Komunitas Keamanan ASEAN. Pertama, masih ada negara-negara yang memiliki dan memilih reaksi dengan mempertimbangkan kekuatan militer yang dikhawatirkan akan menuju kemungkinan perang bersama. Kedua, ASEAN tidak mampu mencegah Filipina dan Vietnam untuk mengerahkan kekuatan, yang dikhawatirkan akan mengarah kepada perlombaan senjata atau kemampuan militer yang ditujukan kepada satu sama lain. Ketiga, pihak-pihak yang terlibat langsung tidak mematuhi tata norma perilaku yang berlaku di wilayah

${ }^{1}$ Istilah China sesuai dengan Surat Edaran Presidium Kabinet Ampera Nomor
SE-o6/Pred.Kab/6/1967 tanggal 28 Juni 1967 dimana istilah "Tiongkok atau
Tionghoa"menjadi "Tjina" (Cina). Dengan demikian, istilah South China Sea
diterjemahkan dalam bahasa Indonesia sebagai Laut China Selatan. Namun,
sejak lahirnya Keputusan Presiden (Keppres) Nomor 12 Tahun 2014, istilah
China kembali menggunakan istilah Tionghoa atau Tiongkok. Keppres tersebut
mencabut yang mencabut Surat Edaran Ampera.

2 Penulis tidak memakai kata "pihak" dan bukan "negara" karena adanya "OneChina Policy" dalam masalah penyebutan terhadap Taiwan. Indonesia mengakui "One-China Policy" dan tidak menganggap Taiwan sebagai negara tersendiri. 
Laut Tiongkok Selatan. ASEAN juga gagal bermufakat untuk satu pendapat mengenai kode tata perilaku di LTS dan pemberian sanksi bila terjadi suatu insiden. Dengan demikian, sulit membayangkan Komunitas Keamanan ASEAN terwujud dalam waktu dekat.

Penelitian ini menggunakan pendekatan kualitatif historis. Kualitatif historis adalah pendekatan metodologis yang meletakkan kualitatif maupun pengukuran kuantitatif dan menggunakan dokumen historis atau intepretasi sejarawan untuk menggunakan dan menguji teori (Thies 2002, 352). Istilah yang digunakan ini bukanlah untuk menggambarkan pendekatan baru dalam studi Hubungan Internasional, tetapi menekankan pada pendekatan metodologis yang sebenarnya selama ini telah menjadi tradisi dalam keilmuan Hubungan Internasional.

Penelitian ini memanfaatkan fakta sejarah yang digunasesuaikan dengan orientasi teoritis. Dalam desain penelitian, peneliti menggunakan sejarah sebagai informasi dasar. Informasi ini kemudian diolah sebagai data awal, kemudian proses validasi dilakukan dengan triangulasi data (Thies 2002, 353). Proses analisis data yang digunakan dalam penelitian ini merujuk pada Thies (2002) adalah sebagai berikut: Pertama, menyeleksi sumber. Sumber dalam penelitian ini adalah dokumen negara, komentar dan pendapat pelaku diplomasi, pendapat para ahli, dan dokumen cetak maupun elektronik yang tidak berasal dari pemerintah. Kedua, menentukan sumber utama. Sumber utama dalam penelitian ini adalah pelaku diplomasi, dokumen resmi pemerintah berkaitan dengan LTS. Untuk mendapatkan informasi ini, penulis melakukan kajian di perpustakaan Ali Alatas Kementerian Luar Negeri dan melakukan wawancara dengan diplomat senior dan ahli. Ketiga, menentukan sumber sekunder. Sumber sekunder dari penelitian ini adalah dokumen cetak maupun elektronik yang dapat digunakan untuk mengkonfirmasi sumber utama. Untuk validasi data, penelitian ini menggunakan strategi men-triangulasi (triangulated) sumber-sumber data yang berbeda dengan memeriksa bukti-bukti yang berasal dari sumber tersebut dan menggunakannya untuk membangun justifikasi tema-tema secara koheren.

\section{Komunitas Keamanan sebagai Kerangka Teori}

Penelitian ini menggunakan komunitas keamanan sebagai dasar kerangka teori. Kajian teori mengenai komunitas keamanan tercatat pertama kali ditawarkan oleh Karl Deutsch. Menurut Deutsch (1961),

"A security community is considered to be a group which has become integrated, where integration is defined as the attainment of a sense of community accompanied by formal and informal institutions and practices, sufficiently strong and widespread to 
assure peaceful change among members of a group with reasonable certainty over a long period of time."

Dengan demikian, komunitas keamanan memiliki beberapa poin berikut: (1) dibentuk oleh dua atau lebih unit politik, (2) memiliki banyak transaksi dan interaksi yang terus-menerus, (3) bertujuan untuk menjamin perdamaian di antara sesama anggota dalam waktu yang lama, dan (4) tercapainya integrasi berupa "we feeling" di antara para penduduk.

Deutsch kemudian membagi komunitas keamanan menjadi dua tipe (Luhulima et.al. 2008, 74). Tipe pertama adalah Amalgamated Security Community (ASC). Tipe ini terjadi ketika dua unit atau lebih yang independen bergabung membentuk suatu pemerintahan yang lebih besar. Tipe kedua adalah Pluralistic Security Community (PSC). Tipe ini terjadi ketika unit-unit ini membentuk suatu institusi bersama yang independen secara politik dan hukum. Luhulima et.al. (2008, 76-77) menulis bahwa ASEAN merupakan contoh dari PSC dan bisa dikategorikan sebuah komunitas keamanan yang longgar.

\section{Sengketa Laut Tiongkok Selatan dan Dinamika Intra-ASEAN}

Keenam pihak yang terlibat klaim di LTS memiliki klaim yang saling tumpah tindih. Tiongkok, Taiwan, dan Vietnam cenderung melakukan klaim wilayah terhadap seluruh Kepulauan Spratly, sementara Malaysia, Filipina, dan Brunei Darussalam hanya menuntut sebagian pulau-pulau dari kepulauan tersebut (lihat Tabel 1).

\section{Tabel 1. Tahun Rilis Peta dan Wilayah Klaim}

\begin{tabular}{lll}
\hline AKTOR & MERILIS PETA & WILAYAH KLAIM \\
\hline Tiongkok & 1947 & Kep. Spratly \& Paracel \\
Taiwan & 1947 & Kep. Spratly \& Paracel \\
Vietnam & 1976 & Kep. Spratly \& Paracel \\
\hline Filipina & 1978 & 60 pulau, karang, dan atol \\
Malaysia & 1979 & 11 pulau, karang, dan atol \\
Brunei Darussalam & - & 1 karang (Louisa Reef) \\
\hline
\end{tabular}

(Chi-Kin Lo 1989; Asnani \& Rizal Sukma 1997; Dam 2010; Djalal et.al., 1995)

Dasar klaim keenam negara berbeda satu sama lain. Empat negara melakukan klaim atas dasar historis, yaitu Tiongkok, Taiwan, Vietnam, dan Filipina. Kalau diamati, keempat negara inilah yang selalu saling provokasi dan terlibat insiden-insiden di LTS. Selain itu, empat negara melakukan klaim atas dasar UNCLOS 1982. Meskipun ada beberapa 
mekanisme dalam UNCLOS, hal ini sulit dilakukan karena dua pihak lain, yaitu Tiongkok dan Taiwan, tidak melakukan klaim atas dasar UNCLOS. Taiwan juga tidak meratifikasi UNCLOS.

Mengenai kepentingan negara-negara anggota ASEAN yang berkaitan dengan LTS, penulis membaginya dalam dua kelompok. Kelompok pertama, pihak atau negara-negara pesisir yang terlibat klaim langsung, seperti Filipina, Vietnam, Malaysia, dan Brunei Darussalam. Pihakpihak tersebut memiliki kepentingan kedaulatan dan kepentingan ekonomi. Kepentingan kedaulatan membuat negara-negara tersebut enggan menyerahkan wilayah yang mereka klaim di LTS. Mereka berusaha menduduki wilayah tersebut, bila perlu dengan menempatkan kekuatan militernya (Djalal 2015). Sementara dalam hal kepentingan ekonomi, seperti hasil penelitian International Crisis Group (2012), klaim yang seringkali berujung kepada konfrontasi kecil tersebut rupanya berjalan seiringan dengan kebutuhan dan penurunan ekonomi dalam negeri di negara-negara pengklaim. Di Vietnam, harga-harga bahan pokok semakin tinggi, mata uang melemah, dan lowongan lapangan kerja yang stagnan, membuat negara itu memiliki legitimasi untuk menengok dan memanfaatkan potensi sumber daya di LTS.

Pada tahun 2007, pemerintah Vietnam mengeluarkan Strategi Maritim $202 O$ yang bertujuan untuk meningkatkan hasil ekonomi dari sektor maritim, terutama dari minyak dan gas, dari 48 persen GDP pada tahun 2005 ke 55 persen GDP pada tahun 2020. Pada tahun 2010, sektor industri perikanan Vietnam menjadi lumbung pendapatan negara dengan menempati urutan kedua terbesar perdagangan luar negeri sebesar 7 persen dari total pendapatan ekspor sejumlah 71,6 juta dollar AS. Sementara Filipina mengalami penurunan FDI (Foreign Direct Investment) yang sangat signifikan sampai 31 persen dari Februari 2011 ke Februari 2012. Filipina juga mengalami peningkatan defisit anggaran dan perdagangan besar. Dengan menguasai sumber daya alam di LTS, negara-negara tersebut berharap dapat terus menumbuhkan ekonomi dalam negerinya.

Kelompok kedua, negara-negara pesisir Asia Tenggara yang memiliki kepentingan besar, yaitu Indonesia dan Singapura. Negara-negara Asia Tenggara lainnya seperti Thailand, Myanmar, Kamboja, dan Laos tidak secara kuat terlibat dalam sengketa LTS meskipun ikut menandatangani DOC. Masih menjadi pertanyaan di kalangan pengamat hubungan internasional, termasuk Prof. Hasjim Djalal, apakah negara-negara ini bisa digolongkan sebagai pihak yang terlibat. Namun, menurut penulis, minimal negara-negara ini memiliki kepentingan atas stabilitas kawasan yang bisa berakibat pada ekonomi dalam negeri tiap-tiap negara. Perbedaan kepentingan ini nantinya yang turut menentukan 
pernyataan, sikap, atau perilaku negara anggota ASEAN terhadap sengketa LTS.

\section{Implikasi Terhadap Komunitas Keamanan ASEAN}

Menurut Karl Deutsch (dalam Holsti 1988), setidaknya ada tiga hal yang perlu dilihat di antara negara-negara yang ingin membentuk masyarakat keamanan. Pertama, para pembuat kebijakan dua unit politik atau lebih dan masyarakat pada umumnya berhenti merenungkan kemungkinan perang bersama. Kedua, dua negara atau lebih berhenti mengalokasikan sumber daya untuk membangun kemampuan militer yang ditujukan kepada satu sama lain. Ketiga, ada penerimaan dan kepatuhan yang ketat terhadap aturan-aturan dan perjanjian tertentu bila tujuan kolektif unit-unit tidak selaras. Tiga hal itulah yang mampu menciptakan Komunitas Keamanan ASEAN yang ditargetkan tercapai pada 2015. Berikut bagan alur pemikiran tersebut:

Gambar 1. Menuju Komunitas Keamanan

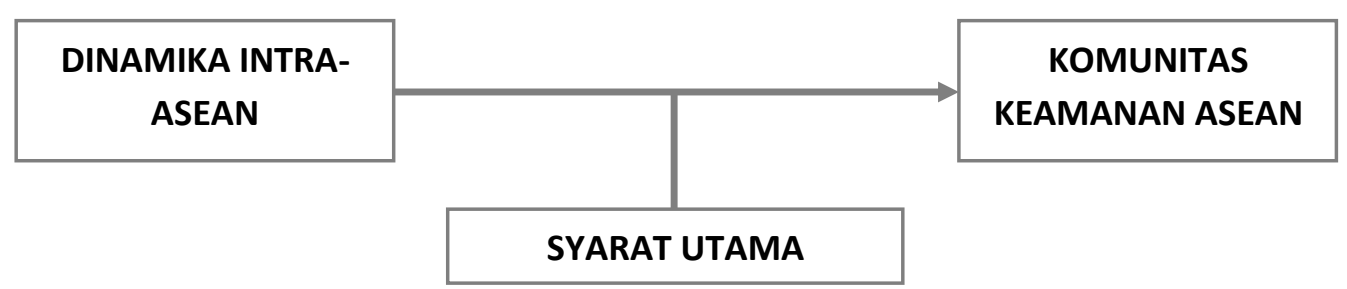

- Para pembuat kebijakan dan masyarakat berhenti merenungkan kemungkinan perang bersama.

- Negara-negara berhenti mengalokasikan sumber daya untuk membangun kekuatan militer yang ditujukan satu sama lain.

- Terdapat penerimaan dan kepatuhan terhadap

\section{Pembicaraan Kemungkinan Perang}

Selama ini, negara-negara yang terlibat klaim langsung telah mengadakan kerja sama bilateral. Namun, pertemuan mengenai kerja sama tersebut diikuti oleh berbagai pernyataan yang memanaskan situasi dari pejabat dan rakyat dari negara-negara yang bersengketa. Di antara negara-negara ASEAN, Filipina dan Vietnam merupakan dua negara yang paling keras mengemukakan mengenai kemungkinan perang. Misalnya, dalam pidato peringatan kemerdekaan Filipina ke-115 pada tanggal 12 Juni 2013, Presiden Benigno Aquino III menegaskan 
bahwa Filipina tidak akan surut menghadapi hal-hal yang mengancam kedaulatan dan teritorial Filipina, termasuk jika harus berhadapan dengan Tiongkok.

Komentar-komentar pejabat tersebut secara umum mengindikasikan adanya bahaya militer dan perang yang mungkin terjadi di masa depan. Dalam prakteknya, Vietnam dan Filipina melakukan latihan militer dengan Amerika Serikat. Perilaku tersebut mencerminkan perilaku yang "tidak bersahabat" dan mendapat reaksi keras dari Tiongkok. Pada tanggal 13 Juni 2011, misalnya, ketika Vietnam latihan militer dengan amunisi tajam di sekitar Spartly, Tiongkok menanggapi dengan menyebutnya "kekuatan militer untuk melawan Beijing". Di sini perkatan "kekuatan militer" bahkan telah digunakan untuk merespon pergerakan negara lain.

Dengan demikian, tiga hal yang menyulitkan pada poin pertama ini adalah muncul pernyataan-pernyataan curiga dari elit, terutama dari negara kubu pertama, tindakan yang dianggap tidak bersahabat seperti latihan militer, dan demo dari rakyat yang menyuarakan kekerasan dan penggunaan kekuatan militer.

\section{Perlombaan Senjata}

Komunitas keamanan tidak hanya dilihat dari pembicaraan kemungkinan adanya perang, namun juga ketiadaan persiapan yang signifikan untuk berperang. Perlombaan senjata, sebagaimana yang dituturkan Barry Buzan, adalah "self-stimulating military rivalry between states, in which their efforts to defend themselves militarily cause them to enhance the threats they pose to each other" (Acharya 2009, 137-138). Dari situ empat hal yang perlu diamati. Pertama, belanja militer dari tahun ke tahun. Kedua, pendudukan dan pembangunan instalasi militer di LTS. Ketiga, modernisasi militer.

Mengenai hal pertama, seperti data yang diambil dari SIPRI (2014) di bawah ini, perkembangan militer negara-negara pengklaim dari ASEAN pasca-penandatanganan DOC tahun 2002 sebenarnya tidak terlalu signifikan. 
Tabel 2. Pengeluaran Belanja Militer Negara Pengklaim (dalam Juta Dollar AS)

\begin{tabular}{|c|c|c|c|c|}
\hline$\overline{\mathrm{Ne}}$ & Vietnam & Filipina & Malaysia & Brunei D. \\
\hline 2003 & 1366 & 2282 & 4052 & 332 \\
\hline 2004 & 1399 & 2127 & 3910 & 262 \\
\hline 2005 & 1459 & 2145 & 4183 & 318 \\
\hline 2006 & 1718 & 2202 & 4094 & 357 \\
\hline 2007 & 2215 & 2414 & 4571 & 370 \\
\hline 2008 & 2183 & 2391 & 4674 & 381 \\
\hline 2009 & 2397 & 2322 & 4413 & 374 \\
\hline 2010 & 2697 & 2438 & 3859 & 391 \\
\hline 2011 & 2675 & 2417 & 4587 & 414 \\
\hline 2012 & 3128 & 2793 & 4664 & 407 \\
\hline 2013 & 3025 & 3208 & 4809 & 402 \\
\hline
\end{tabular}

(SIPRI 2004)

Dari tabel di atas, negara yang belanja militernya meningkat secara pesat adalah Vietnam, yaitu sekitar 1839 juta dollar AS atau seratus persen lebih dari tahun 2003 sampai 2013. Dalam kurun waktu yang sama, Filipina meningkat 926 juta dollar AS, Malaysia 757 juta dollar AS, dan Brunei Darussalam meningkat 70 juta dollar AS. Data belanja militer ini menunjukkan bahwa Vietnam merupakan negara paling agresif dalam belanja militer sebagai negara dengan belanja militer terbesar di antara negara-negara pengklaim dari ASEAN.

Kedua, mengenai pendudukan dan pembangunan instalasi militer yang telah dilakukan sejak dahulu. Meskipun termasuk belakangan melakukan klaim, sejak tahun 1961 Filipina telah melakukan pendudukan di Pulau Thitu (Pagasa), West York, Loatia, dan Nanshan (Lawak). Filipina membangun instalasi militer di Pulau Thitu atau Pagasa, menempatkan 500 tentara, dan dilanjutkan dengan membangun landasan sepanjang 1200 meter pada tahun 1982 (Djalal 1995, 41). Pada bulan Juni 1983, Malaysia mendaratkan pasukan militernya di Terumbu Layang-Layang atau Da Hoa Lau, yang terletak di sebelah utara negara Malaysia bagian Serawak. Untuk memperkuat kendalinya atas pulau-pulau yang diklaim, Malaysia membuat basis angkatan laut di Sungai Aute, yang terletak di daerah Sibu, Sarawak, dan menempatkan beberapa kapal yang memiliki senjata misil. Meskipun menyiapkan militernya, Malaysia jarang sekali melakukan provokasi militer dan terlibat pertempuran kecil dengan Tiongkok, Vietnam, atau Filipina di LTS. Pendudukan dan pembangunan instalasi militer yang sampai sekarang terus dipertahankan ini membuat potensi perang di kawasan sengketa semakin tinggi. 
Ketiga, modernisasi militer. Filipina, Malaysia, dan Vietnam melakukan modernisasi militer untuk angkatan laut dan penjaga pantainya. Hal ini tidak lepas dari modernisasi militer Tiongkok, meski Menteri Pertahanan Tiongkok Liang Guanglie sempat mengatakan bahwa Tiongkok tidak ingin mengancam negara mana pun dengan modernisasi militernya. Dibandingkan dengan militer Tiongkok, militer negaranegara pengklaim dari ASEAN belum ada apa-apanya. Polisi Laut Vietnam, semenjak berpisah dari struktur tentara pada tahun 2008, baru memiliki 1000 personil. Penjaga pantai Filipina juga dikatakan kurang memiliki pengetahuan tentang kelautan (International Crisis Group 2012, 19). Yang akan lebih menyulitkan, modernisasi militer ini cenderung melibatkan mitra tradisional masing-masing negara. Sebagai contoh, Filipina menganggarkan belanja pertahanan untuk modernisasi militer sebesar 1,74 miliar dollar AS atau Rp 17,3 triliun sampai tahun 2016 saat berakhirnya masa jabatan Presiden Aquino. Alat-alat militer Filipina dipasok oleh sekutunya AS dan Jepang, termasuk sistem radar dan pengembangan pesawat mata-mata (International Crisis Group 2012, 18). Seperti yang diberitakan Kompas (2011), hal tersebut diikuti jaminan AS melalui Menlu AS Hillary Clinton yang menegaskan kepada Menlu Filipina Alberto del Rosario bahwa AS bersedia mempersenjatai angkatan perang Filipina dengan persenjataan yang lebih modern.

Dengan demikian, meskipun belanja militer negara-negara ASEAN tidak meningkat terlalu signifikan, perkembangan militer yang terjadi tetap mengkhawatirkan (Mangindaan 2015). Sebagaimana dicatat oleh Amitav Acharya (2009), Presiden Filipina Fidel Ramos menyebutnya dengan "a mini-arms race of sorts", sementara analis Australia menyebut apa yang terjadi dengan suatu "slow motion arms race". Perkembangan militer ini, bagaimana pun, berpotensi menimbulkan ancaman jangka panjang dan kecurigaan antarnegara di kawasan, serta kontras dengan prinsip good-neighbourliness dan hasrat untuk mewujudkan stabilitas regional (status quo).

\section{Peraturan dan Kepatuhan}

Dua dokumen penting ASEAN yang terkait dengan masalah keamanan adalah ZOPFAN dan TAC. Dalam ZOPFAN, negara-negara diminta sepakat untuk menerima berbagai langkah dan sikap untuk saling menahan diri. Dalam TAC, negara-negara diminta untuk menyelesaikan masalah dengan cara damai. Untuk sengketa LTS, dokumen yang juga penting adalah DOC, yang dideklarasikan tahun 2002. Namun DOC tidak mengikat karena hanya berbentuk deklarasi. Bentuk deklarasi hanya semacam statemen politik. Dalam pembicaraan mengenai DOC, bentuk deklarasi tersebut merupakan hasil kompromi, di mana sebelumnya Vietnam menginginkan bentuk kode dan Malaysia 
keberatan dengan bentuk kode tersebut. Bentuk kode akan membuat persetujuan tersebut legal dan mengikat. Namun, atas desakan Vietnam, DOC tersebut kemungkinan akan terus dibicarakan untuk menjadi kode.

DOC yang telah ditandatangani oleh sepuluh negara ASEAN dan Tiongkok berisi beberapa pokok statemen, diantaranya bahwa pihakpihak penandatangan mesti berkomitmen terhadap Piagam Charter PBB, UNCLOS 1982, TAC, dan Lima Prinsip Hidup Secara Damai; menyelesaikan masalah dengan damai tanpa kekerasan melalui konsultasi dan negosiasi bersahabat; menahan diri dari tindakantindakan yang dapat meningkatkan eskalasi konflik, termasuk menambah kehadiran wilayah sengketa. Namun, persetujuan yang berbentuk deklarasi tersebut kurang dipatuhi. Terbukti, berkali-kali terjadi insiden yang melibatkan dua negara anggota ASEAN, yaitu Vietnam dan Filipina. Insiden di wilayah sengketa itu melanggar deklarasi, terutama poin tanpa kekerasan dan tindakan-tindakan yang dapat meningkatkan eskalasi konflik.

Sementara DOC yang bersifat longgar itu sering tidak dipatuhi, kini mulai dibahas COC. COC merupakan persetujuan yang bersifat legal dan mengikat. Beberapa pasal, seperti pasal tentang tujuan (dalam pasal 2) dan dasar ketentuan hampir mirip dengan isi DOC (pasal 3). Poin-poin krusial dalam COC menyebutkan tentang prosedur dan aturan untuk menuntaskan insiden (pasal 6 ayat 2) serta mekanisme penyelesaian sengketa (pasal 8). Dalam Draf Nol COC juga disebutkan, COC tidak boleh digunakan untuk menolak klaim pihak lain untuk memperkuat klaim suatu negara di wilayah yang disengketakan (pasal 5). Selain itu, COC juga memerinci pelarangan seperti dilarang mengarahkan senjata atau peluncur peluru kendali ke arah pihak lain, kecepatan kapal dan jarak aman antarkapal, serta bagaimana dan apa tahapan yang perlu dilakukan bila ada kapal suatu negara yang rusak di perairan sengketa (pasal 6).

Negara-negara ASEAN tidak ingin COC menganggu atau menghambat kepentingan mereka. Tapi setiap negara juga berkepentingan agar insiden di LTS tidak terulang terus menerus. Dalam COC, sesuai sifatnya yang formal dan legal, dicantumkan bahwa semua pihak harus secara ketat mematuhi upaya mendorong rasa saling percaya dan pencegahan insiden. Di dalamnya termasuk negara-negara harus menahan diri untuk tidak menggelar latihan militer di sekitar wilayah sengketa atau aksi provokasi lain yang bisa menimbulkan ancaman bagi negara lain, juga dilarang membangun pulau yang disengketakan. Oleh karena itu, meskipun ada perbedaan pendapat, tidak ada negara yang menolak Draf Nol yang diajukan Indonesia. Semua sepakat bahwa Draf Nol akan menjadi rujukan dalam pembahasan mengenai COC selanjutnya. 
Dari penjelasan yang dipaparkan di atas, bagan menuju Komunitas Keamanan ASEAN terlihat pada gambar berikut:

\section{Gambar 2. Fakta-Fakta Sengketa Laut Cina Selatan}

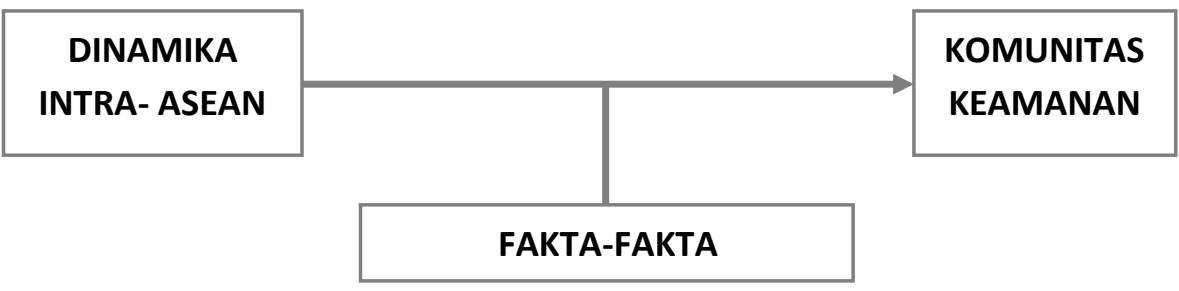

- Vietnam dan Filipina mengirimkan militernya di wilayah yang diklaim dan melakukan latihan perang di dekat wilayah sengketa. Sering sekali terjadi konfrontasi kecil. Tindakan tersebut dianggap sebagai intimidasi dan ancaman oleh Cina, juga sebaliknya.

- Vietnam, Filipina, dan Malaysia meningkatkan anggaran militer dari tahun ke tahun serta melakukan modernisasi militer. Mereka mendapat bantuan militer dari negara-negara mitra seperti Rusia, India, Amerika Serikat, dan Jepang.

- Deklarasi Tata Berperilaku Para Pihak di Laut Cina Selatan (DOC) tidak ditaati oleh negara yang terlibat klaim langsung. Draft Nol Kode Tata Berperilaku (COC) dari Indonesia juga belum disepakati.

\section{Ancaman Terhadap Komunitas Keamanan ASEAN}

Dari analisis ketiga syarat utama pembentuk Komunitas Keamanan ASEAN yang telah dipaparkan sebelumnya, terbentuknya Komunitas Keamanan ASEAN pada tahun 2015 nanti menjadi sebuah tanda tanya besar. Dalam ASEAN Security Communiy Plan of Action yang telah disusun ASEAN, perbedaan sikap tersebut mengganggu pada tiga poin dasar dan penting untuk menuju Komunitas Keamanan ASEAN.

Pertama, mengganggu upaya penyebaran norma-norma ASEAN, seperti prinsip tidak memihak, tidak menggunakan kekerasan, dan tidak saling mengancam menggunakan kekuatan militer. Kedua, mengganggu upaya mekanisme pencegahan konflik agar semua pihak menahan diri dari segala bentuk kekerasan. Ketiga, perbedaan sikap tersebut menyulitkan ASEAN untuk membentuk mekanisme penyelesaian konflik yang jelas dan mengikat untuk memperkuat kepercayaan di antara negara-negara ASEAN. Hal ini semakin berat karena kubu pertama yang tidak segan menggunakan militer dan kubu ketiga yang tidak antusias dalam pembicaraan mengenai LTS belum ada tanda-tanda untuk bekerja sama 
aktif sebagai satu kesatuan ASEAN. Namun demikian, antarnegara anggota ASEAN sebenarnya telah memiliki kata sepakat untuk samasama menyelesaikan masalah sengketa LTS secara damai. Pernyataanpernyataan keras pejabat negara, kekuatan militer, serta suara-suara keras masyarakat yang sering muncul dari Filipina dan Vietnam lebih ditujukan kepada Tiongkok, bukan kepada sesama anggota ASEAN. Negara-negara ASEAN juga telah sepakat untuk masuk pada pembahasan selanjutnya mengenai COC. Dengan ini kita bisa melihat bahwa dinamika intra-ASEAN dengan segala perbedaan pandangan di dalamnya masih mungkin untuk menuju Komunitas Keamanan ASEAN (Djumala 2015).

Di masa depan, ada dua tantangan untuk menuju Komunitas Keamanan ASEAN. Pertama, sikap dan perilaku Tiongkok. Masih muncul penolakan keras dari Tiongkok pada beberapa hal, seperti penerimaan terhadap COC yang bersifat legal, rinci, dan mengikat. Tiongkok pun juga berhasil mempengaruhi Kamboja dalam membuat keputusankeputusan penting saat Kamboja memegang posisi penting sebagai ketua ASEAN. Dalam KTT ASEAN ke-22 pada 24 April 2013 di Bandar Seri Begawan, Brunei Darussalam, Dirjen Kerjasama ASEAN Kementrian Luar Negeri Indonesia Gusti Agung Wesaka Puja mengatakan, perdamaian sudah tekad dari semua negara ASEAN. Kita masih menunggu apakah Tiongkok siap untuk bersama-sama ASEAN membahas itu. Mudah-mudahan tidak ada hambatan, karena dalam konteks unity ASEAN, itu sudah menjadi tekad bersama untuk memajukan isu Laut Tiongkok Selatan ini untuk mencari solusi damai. Selama Tiongkok belum dengan terbuka menerima COC, maka peluang untuk segera tercipta Komunitas Keamanan ASEAN pada tahun 2015 masih lemah.

Kedua, yang berkaitan dengan jabatan ketua ASEAN. Pada tahun 2011, Indonesia yang menjabat sebagai ketua ASEAN menjadikan masalah LTS sebagai prioritas utama keberhasilan. Indonesia sangat aktif mengusahakan masalah ini di level ASEAN, meskipun insiden-insiden yang melibatkan militer di kawasan sengketa masih terjadi. Setelahnya, jabatan ketua ASEAN dipegang oleh negara-negara yang masuk dalam kubu yang tidak terlalu antusias dalam masalah sengketa LTS karena tidak memiliki kepentingan secara langsung di wilayah itu. Pada tahun 2012, Kamboja sebagai ketua ASEAN ternyata berhasil didikte oleh Tiongkok. Pada tahun 2013, Brunei Darussalam yang menjabat ketua ASEAN juga belum memperlihatkan perkembangan yang berarti mengenai LTS. Pada tahun 2014, kembali jabatan ASEAN akan dipegang oleh negara yang tidak menunjukkan keaktifan dalam penyelesaian sengketa LTS, yaitu Myanmar. Hal ini tentunya menarik untuk diamati dan diteliti lebih lanjut. 


\section{Simpulan}

Laut Tiongkok Selatan sampai saat ini masih menjadi pembicaraan hangat di kalangan pemerhati hubungan internasional. Semenjak tahun 1990-an, ASEAN mulai membahas masalah LTS ini secara lebih dalam. Dalam akomodasi-akomodasi yang dilakukan ASEAN itulah terjadi perbedaan sikap negara. Perbedaan sikap negara anggota ASEAN yang sangat beragam berimplikasi pada syarat-syarat utama yang mesti dipenuhi untuk menuju pada cita-cita komunitas keamanan. Pertama, gagalnya para pembuat kebijakan dua unit politik atau lebih dan masyarakat pada umumnya untuk berhenti merenungkan kemungkinan perang bersama. Kedua, alokasi dan modernisasi kemampuan militer terus meningkat, sehingga menimbulkan perlombaan senjata. Ketiga, muncul ketidakpatuhan terhadap aturan-aturan dan perjanjian dalam DOC, yang berakibat memperlambat terbentuknya aturan yang lebih mengikat dan legal seperti COC.

Kemudian, kondisi di atas berimplikasi pada rencana aksi yang disusun ASEAN untuk menuju Komunitas Keamanan ASEAN. Setidaknya ada tiga dasar penting yang terhambat dalam ASEAN Security Community Plan of Action. Pertama, perbedaan sikap itu mengarah pada gangguan penyebaran norma-norma ASEAN, seperti prinsip tidak memihak, tidak menggunakan kekerasan, dan tidak saling mengancam menggunakan kekuatan militer. Kedua, perilaku yang ditunjukkan beberapa negara mengganggu upaya mekanisme pencegahan konflik agar semua pihak menahan diri dari segala bentuk kekerasan. Ketiga, perbedaan sikap tersebut menyulitkan ASEAN untuk membentuk mekanisme penyelesaian konflik yang jelas dan mengikat untuk memperkuat kepercayaan di antara negara-negara ASEAN.

\section{Daftar Pustaka}

\section{Buku, Jurnal, dan Dokumen Resmi}

Acharya, Amitav, 2009. Constructing a Security Community in Southeast Asia: ASEAN and The Problem of Regional Order $2^{\text {nd }}$ ed. New York: Routledge.

Asnani, Usman \& Rizal Sukma, 1997. Konflik Laut Tiongkok Selatan: Tantangan bagi ASEAN, Jakarta: Centre for Strategic and International Studies.

Bateman, Sam \& Ralf Emmers (eds.), 2009. Security and International Politics in the South China Sea: Towards a cooperative management regime, New York: Routledge. 
Cipto, Bambang, 2007. Hubungan Internasional di Asia Tenggara, Yogyakarta: Pustaka Pelajar.

Cooper, B. (ed.), 1981. Far East Oil and Energy Survey 1981, Geneva and Dublin: Petroleum Economics and Petroconsultantas.

Dam, Syamsumar, 2010. Politik Kelautan, Jakarta: Bumi Aksara.

Darmawan, Arief B. 2012, Implikasi Dinamika Intra-ASEAN dalam Sengketa Laut Cina Selatan terhadap Komunitas keamanan ASEAN. Skripsi: Departemen Ilmu Hubungan Internasional FISIP UGM.

Deutsch, Karl W. 1961. Security Communities, di dalam buku James Rosenau (ed.), International Politics and Foreign Policy, New York: Free Press.

Djalal, Hasjim, 1996. Posisi Negara-Negara Besar Menghadapi Potensi Konflik di Laut Tiongkok Selatan. Makalah penelitian yang dipresentasikan dalam Forum Dialog Politik dan Keamanan dalam Era Pasca Perang Dingin: Tujuan dan Fungsinya, Yogyakarta, 7-10 Januari 1996.

Djalal, Hasjim, et.al., 1995. Usaha-Usaha Mengalihkan Potensi Konflik di Laut Tiongkok Selatan Menjadi Potensi Kerjasama. Makalah penelitian Proyek Penelitian dan Pengembangan Politik Luar Negeri Yayasan Pusat Studi Asia Tenggara dengan Badan Penelitian dan Pengembangan Departemen Luar Negeri Republik Indonesia, Jakarta: Yayasan Pusat Studi Asia Tenggara.

Ellings, Richard J. dan Sheldon W. Simon, 1996. Southeast Asian Security in the New Millennium, Armonk, New York: M.E. Sharpe.

Emmers, Ralf, 200o. "Maritime Disputes in the South China Sea: Strategic and Diplomatic Status Quo", dalam Kwa Chong Guan and John K. Skogan (eds), 2000. Maritime Security in Southeast Asia, New York: Routledge.

Gee, Lim Teck dan Mark J. Valencia, 1990. Conflict over Natural Resources in South-East Asia and the Pacific, Manila: Ateneo de Manila University Press.

Holsti, K. J., 1988. Politik Internasional: Kerangka untuk Analisis, Edisi ke-4 Jilid 2 (terj. M. Tahir Azhary). Jakarta: Penerbit Erlangga.

International Crisis Group, 2012. Stirring up the South China Sea (II): Regional Respon-ses.

Lo, Chi-Kin, 1989. China's Policy Toward Territorial Disputes: The Case of the South China Sea Islands, London and New York: Routledge.

Luhulima, CPF., et. al., 2008. Masyarakat Asia Tenggara Menuju Komunitas ASEAN 2015. Yogyakarta: Pustaka Pelajar. 
Roberts, Christopher, 2010. ASEAN's Myanmar Crisis: Challenges to the Pursuit of a Security Community, Singapore: Institute of Southeast Asian Studies.

Departemen Luar Negeri Republik Indonesia, 1997. Sejarah Diplomasi Republik Indonesia dari Masa ke Masa:Buku IV A Periode 19661995 (Masa Orde Baru). Jakarta: Departemen Luar Negeri Republik Indonesia.

Departemen Luar Negeri Republik Indonesia, 1998. Sejarah Diplomasi Republik Indonesia dari Masa ke Masa:Buku IV B Periode 19661995 (Masa Orde Baru). Jakarta: Departemen Luar Negeri Republik Indonesia.

Singh, Daljit et.al. (eds.), 2011. Southeast Asian Affairs 2011, Singapore: Institute of Southeast Asian Studies.

Storey, Ian, 2011. Intra-ASEAN Dynamics and the South China Sea Dispute: Implications for the $\mathrm{DoC} / \mathrm{CoC}$ Process and ZoPFFC Proposal, Makalah penelitian dalam The Third International Workshop "The South China Sea: Cooperation for Regional Security and Development", Hanoi, Vietnam, 3-5 November 2011.

Thies, Cameron G, 2002. A Pragmatic Guide to Qualitative Historical Analysis in the Study of International Relations. International Studies Perspectives 3: 351-372.

Weatherbee, Donald E, 2005. International Relations in Southeast Asia The Struggle for Autonomy, Lanham: Rowman \& Littlefield Publishers, Inc.

Zhiguo, Gao, 2005. "South China Sea: Turning Suspicion into Mutual Understanding and Cooperation", dalam Saw Swee-Hock, Sheng Lijun, and Chin Kin Wah (eds), 2005. ASEAN-China Relations: Realities and Prospects, Singapura: ISEAS Publishing.

\section{Internet}

Buszynski, Leszek, 2003. ASEAN, the Declaration of Conduct, and the South China Sea, Contemporary Southeast Asia 25 (3): 343-362 [online] dalam <http://search.ebscohost.com/login.aspx?direct=true\&db=a9h\&A $\mathrm{N}=12320688 \&$ site $=$ ehost-live $>$ [diakses 25 Februari 2015].

Buszynski, Leszek. The South China Sea: Oil, Maritime Claims, and U.S.-China Strategic Rivalry. CSIS Online [online] dalam <http://csis.org/files/publication/twq12springbuszynski.pdf> [diakses 25 Februari 2015].

Gomez E., 2001. Marine Scientific Research in the South China Sea and Environmental Security. Ocean Development \& International Law 32 (2): 205-211 [online] dalam <http://search.ebscohost.com/login.aspx?direct=true\&db=a9h\&A $\mathrm{N}=4425178 \&$ site $=$ ehost-live $>$ [diakses 25 Februari 2015]. 
Institute, S. I, 2014. Recent Trends in Military Expenditure. SIPRI. [online] dalam <http://www.sipri.org/research/armaments/milex/resultoutput/tr ends $>$ [diakses 1 Juli 2014].

Kaplan, Robert D., 2011. The South China Sea is the Future of Conflict. Foreign Policy Online. September/ Oktober [online] dalam <http://www.foreignpolicy.com/articles/2011/08/15/the_south_ch ina_sea_is_the_future_of_conflict?page $=0,0>$ [diakses 25 Februari 2015].

Minsky, Sean, 2015. Crowded Waters: The South China Sea's Next Big Flashpoint. [online] dalam <nationalinterest.org/feature/crowdedwaters-the-south-china-seas-next-big-flashpoint-12184> [diakses 14 Maret 2015].

SIPRI, 2014. Recent Trends in Military Expenditure [online] dalam <http://www.sipri. org/research/armaments/milex/ resultoutput/trends $>$, diakses pada 1 Desember 2014.

Chinaschope. t.t. South China Sea Issue: The U.S. Moves from Neutrality to High-Profile Intervention [onine] dalam $<$ http://search.ebscohost.com/login.aspx?direct=true\&db=a9h\&A $\mathrm{N}=60307657 \&$ site $=$ ehost-live $>$ [diakses 25 Februari 2015].

\section{Terbitan Berkala - Koran dan Majalah}

Pattiradjawane, René L, 2012. "Konflik adalah Pilihan, Bukan Keharusan", Kompas, 7 April, hlm. 8.

Sukma, Rizal, 2012. "ASEAN dan Sengketa Laut China Selatan", Kompas, 11 April, hlm. 7.

Pattiradjawane, René L, 2012. "Segregasi Solusi Laut China Selatan", Kompas, 7 Juli, hlm. 9.

Pattiradjawane, René L, 2012. “ASEAN Dipecah Belah China”, Kompas, 18 Juli, hlm. 10.

Dewabrata, Wisnu, 2012. "Indonesia, ASEAN, Laut Tiongkok Selatan", Kompas, 14 Oktober, hlm. 10.

Oegroseno, Arif Havas, 2014. "Teka-teki Laut Tiongkok Selatan", Kompas, 5 Juli, hlm. 7. 